\title{
THE EVOLUTION OF DOMINANCE UNDER DISRUPTIVE SELECTION
}

\author{
C. A. CLARKE and P. M. SHEPPARD \\ Department of Medicine and Department of Zoology, \\ University of Liverpool
}

Received 6.iii.59

\section{INTRODUCTION}

IN a paper on the effects of disruptive selection, Mather (1955) pointed out that if there are two optimum values for a character and all others are less advantageous or disadvantageous there will be disruptive selection which can lead to the evolution of a polymorphism. Sheppard (1958) argued that where such selection is effective and the change from one optimum value to the other is switched by a single pair of allelomorphs there will be three genotypes but only two advantageous phenotypes. Consequently if dominance were absent initially it would be evolved as a result of the disruptive selection, the heterozygote and one of the homozygotes both coming to resemble one of the two optimum phenotypes (see Ford, 1955, on Triphona comes). Thoday (1959) has shown by means of an artificial selection experiment that, even when a character is, at the beginning, controlled polygenically (sternopleural chaeta-number in Drosophila) and there is $5^{\circ}$ per cent. gene exchange between the "high" and "low" selected sub-populations, a polymorphism can evolve.

The most fully understood examples of disruptive selection (other than sex) are provided by instances of Batesian Mimicry, where there are a number of distinct warningly coloured species, acting as models, which are mimicked by the polymorphic forms of a single more edible species. Fisher and Ford (see Ford, 1953) have argued that a sufficiently good resemblance between mimic and model is not likely to arise by chance as the result of mutation. They therefore suggest that a mutant arises which gives a fair resemblance and that there is subsequent selection for modifiers which improve the resemblance controlled by the new mutant. However, if as Fisher (1928) believes, the effects of a new mutant are neither fully dominant nor fully recessive from the beginning, the modification of the phenotype towards more perfect mimicry would also involve the evolution of dominance since normally there will be only two optimum patterns, the mimetic and the original one.

\section{MATERIAL}

In the course of an investigation into the genetics of the highly polymorphic mimetic butterfly Papilio dardanus Brown, we have obtained information which gives data on the evolution of dominance in a polymorphic species. $P$. dardanus is found in the Ethiopian region and occurs in several distinct races whose names 
and geographical distribution are given in fig. I (for a detailed review see the excellent papcr of Ford, 1936). The races which particularly concern us in this paper are (I) the South African race cenea (not to be confused with the mimetic form of the same name, which is found commonly in South Africa and mimics Amauris albimaculata and Amauris echeria), (2) the West African race dardanus, (3) the transitional race meseres, and (4) the Kenya race polytrophus. All these will be collectively known as the main African stock in this paper, since there is some gene exchange between them. Besides these races we shall also be considering two isolated ones, meriones from Madagascar and antinorii from Abyssinia.

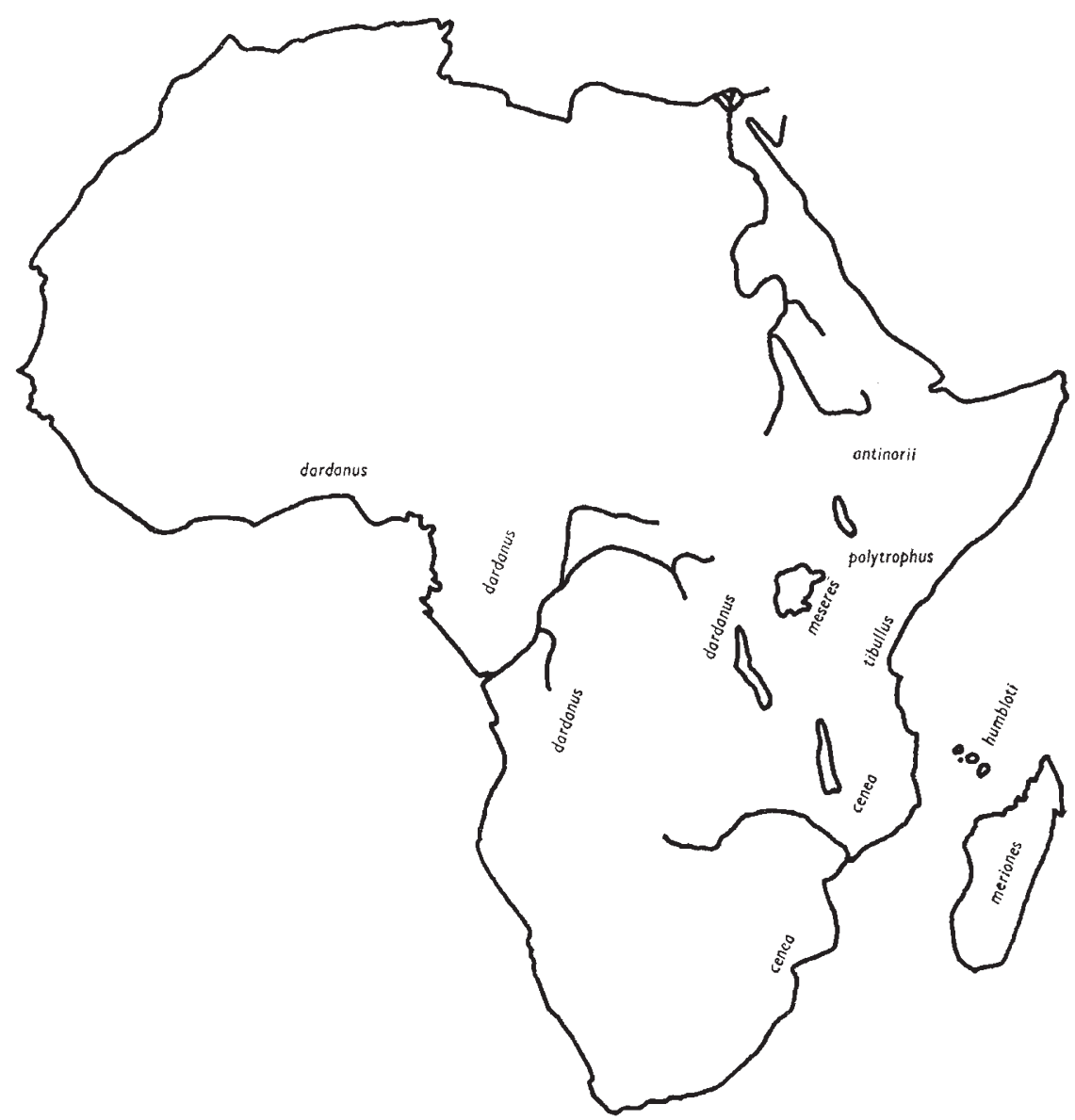

Fig. 1.

In $P$. dardanus the males are all rather similar in appearance having a black and yellow pattern which is non-mimetic and possessing " tails" on their hind wings, a character typical of the genus Papilio. In the main African stock the females are usually mimetic, always tailless, and, with the exception of some individuals in the polytrophus race, never have the yellow fluorescent pigment characteristic of the males. In Madagascar, as well as in race humbloti from Grand Comoro, the females are similar to the males in pattern, in possessing yellow fluorescent pigment and in being tailed. In Abyssinia all the females are tailed and the majority are like the males, but a minority have mimetic patterns. 


\section{METHODS}

The main variation of wing pattern in the forms to be considered occurs in three areas on the forewing and two on the hindwing. For convenience of description these areas have been given numbers in fig. 2. Two other areas of interest are the cells of fore and hind wings which are also marked in the figure.

Besides the wing pattern, there is also variation in tail length and in order to measure this it is necessary to determine fixed points of reference on the hindwing. The three points, given in fig. 2 are, $\mathrm{A}$ at the apex of the cell nearest its point of attachment to the body, $\mathrm{C}$ the point where vein 4 reaches the margin of the wing and $B$ the point where a straight line joining the distal end of veins 3 and 5 cuts vein 4. The length of the tail is taken to be the distance $B C$ and the length of the wing to be BA. Because the edge of the wing is scalloped even insects with no tail have a small protuberance which is measured by $\mathrm{BC}$.

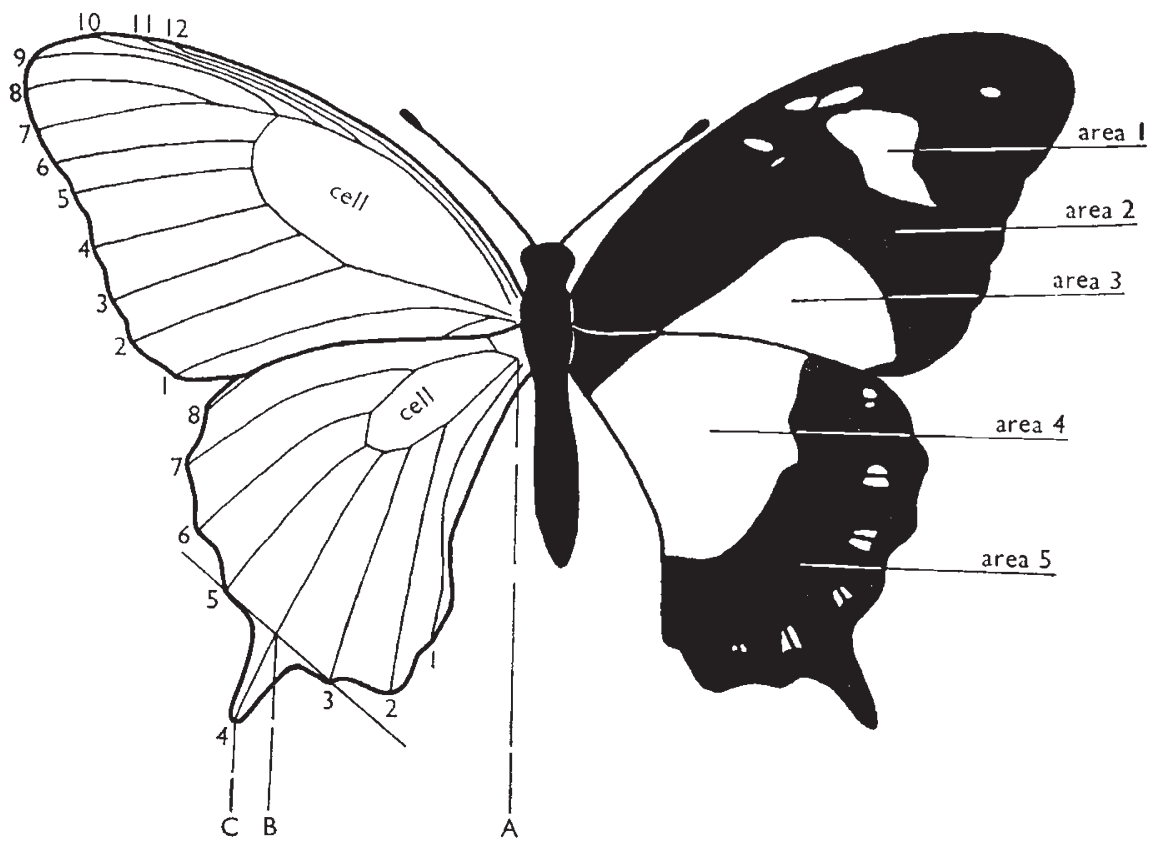

FIG. 2

Since the size of the hindwing varies from insect to insect, from sex to sex and from race to race and since there is a marked correlation between tail length, $\mathbf{B C}$, and wing size, BA, it is necessary to adjust tail length to take into account differences in the size of the insects before comparisons can be made between them. This was done by calculating for each insect the factor which would adjust the length of BA so that it equalled the average $(35.80 \mathrm{~mm}$.) for all insects examined and correcting tail length $\mathrm{BC}$ by this same factor. For example if the length of BA for a particular insect were $38.50 \mathrm{~mm}$. and the tail length were $9 \mathrm{~mm}$. this value would be adjusted by the factor $\frac{35 \cdot 80}{38 \cdot 50}$ to give a length of $8.37 \mathrm{~mm}$.

The procedure would not be legitimate if there were allometric growth. However, such a situation would lead to a correlation between adjusted tail length and unadjusted wing length and as no such correlation is apparent we can conclude that any allometric growth that there may be is too small to be detected in this material and that the procedure of adjusting tail length in accordance with the length of 
the wing is a valid one. Not only does this adjustment reduce differences in mean tail length between the sexes and races but it also materially reduces the sample variance.

\section{THE FEMALE FORMS}

The female forms investigated by us, which occur together in each race (i.e. are sympatric) are given in table I together with some indication as to their frequency

TABLE I

\begin{tabular}{|c|c|c|c|c|}
\hline Race & Female form & $\begin{array}{l}\text { Approximate } \\
\text { frequency } \\
\text { in per cent. }\end{array}$ & Model & $\begin{array}{l}\text { Reference } \\
\text { for } \\
\text { frequency }\end{array}$ \\
\hline cenea & $\begin{array}{l}\text { cenea } \\
\text { hippocoonides } \\
\text { trophonius } \\
\text { natalica } \\
\text { leighi } \\
\text { Imperfect-trophonius } \\
\text { salaami }\end{array}$ & $\begin{array}{l}40-85 \\
9-50 \\
4-15 \\
0-10 \\
<2 \\
1-0 \\
<0 \cdot 2\end{array}$ & $\begin{array}{l}\text { Amauris albimaculata, } \\
\text { A. echeria } \\
\text { A. niavius } \\
\text { Danaus chrysippus } \\
\text { None } \\
\text { None } \\
\text { ? D. chrysippus } \\
\text { None }\end{array}$ & $\begin{array}{l}\text { F., C. } \\
\text { F., C. } \\
\text { F., C. } \\
\text { F., C. } \\
\text { F., C. } \\
\text { cal. } \\
\text { cal. }\end{array}$ \\
\hline $\begin{array}{c}\text { Transitional } \\
\text { and } \\
\text { dardanus }\end{array}$ & $\begin{array}{l}\text { hippocoonides (hippocoon) } \\
\text { planemoides } \\
\text { niobe } \\
\text { trophonius (trophonissa) } \\
\text { cenea } \\
\text { red-brown cenea }\end{array}$ & $\begin{array}{l}60-100 \\
0-40 \\
0-7 \\
0-5 \\
0-7 \\
0-0.4\end{array}$ & $\begin{array}{l}\text { A. niavius } \\
\text { Bematistes poggei } \\
\text { B. tellus } \\
\text { D. chrysippus } \\
\text { A. echeria, } \\
\text { A. albimaculata } \\
\text { None }\end{array}$ & $\begin{array}{l}\text { F. } \\
\text { F. } \\
\text { F. } \\
\text { F. } \\
\text { F. } \\
\text { cal. }\end{array}$ \\
\hline polytrophus & $\left.\begin{array}{l}\text { cenea } \\
\text { proto-cenea } \\
\text { hippocoonides } \\
\text { yellow } \\
\text { (proto-hippocoonides) } \\
\text { pale-poultoni } \\
\text { bright-poultoni } \\
\text { trophonius } \\
\text { proto-trophonius } \\
\text { planemoides } \\
\text { proto-planemoides }\end{array}\right\}$ & $\begin{array}{l}20-40 \\
5^{-I} 5 \\
20-40 \\
3^{-I O} \\
\\
5^{-I} 5 \\
<\text { I } \\
5^{-15} \\
5^{-I} 5\end{array}$ & $\begin{array}{l}\text { A. echeria, } \\
\text { A. albimaculata } \\
\text { ? A. echeria, } \\
\text { A. albimaculata } \\
\text { A. niavius } \\
\text { ?A. niavius } \\
\\
\text { None } \\
\text { D. chrysippus } \\
\text { ? D. chrysippus } \\
B . \text { poggei } \\
\text { ? B. poggei }\end{array}$ & $\begin{array}{l}\text { F. } \\
\text { F. } \\
\text { F. } \\
\text { F. } \\
\text { F. } \\
\text { F. } \\
\text { F. } \\
\text { F. }\end{array}$ \\
\hline antinorii & $\begin{array}{l}\text { yellow (male-like) } \\
\text { hippocoonides (niavioides) } \\
\text { trophonius (? ruspinae) } \\
\text { wienholti } \\
\text { cenea }\end{array}$ & $\begin{array}{l}80-1 \text { oo } \\
\text { O-2O } \\
\text { O-5 } \\
\text { O-I } \\
\text { O-I }\end{array}$ & $\begin{array}{l}\text { None } \\
\text { A. niavius } \\
D . \text { chrysippus } \\
\text { ? B. epaea and } \\
\text { ? Acraea jodutta } \\
\text { A. echeria }\end{array}$ & $\begin{array}{l}\text { M. } \\
\text { M. } \\
\text { M. } \\
\text { M. } \\
\text { M. }\end{array}$ \\
\hline meriones & yellow (male-like) & 100 & None & F. \\
\hline
\end{tabular}

In the references C. stands for Clarke et al., cal. for calculated, F. for Ford and M. for Museum and Mansfield collections.

and mimetic status. Where two colour patterns are controlled by the same main allelomorph but differ in appearance because of differences in the gene-complexes of the various races they have usually been given different names by entomologists. 
In the table we have used one name for these genetically similar forms but have put in brackets the varietal name used by entomologists.

The patterns are described with reference to the areas marked on fig. 2. Owing to the difficulty of describing colours accurately, where necessary, the reference numbers of the colour of a typical specimen have been taken from Villalobos and Villalobos (1947) and are put in parentheses. The numbers are given in the order hue, value and degree respectively.

cenea (plate 3, no. 6) has the pale area 4 of the hindwing yellowish-buff (8-18-8) and the spots on the forewing are white to pale yellowish-buff.

hippocoonides (plate 3 , no. 4) has all the pale areas white. The width of area 5 varies from race to race in parallel with that of a similar area on the local sub-species of the model.

trophonius has the same black pattern as hippocoonides except that area 5 is always narrow, as is a similar area on its model. Areas 3 and 4 are reddish-brown (7-16-12) and area $\mathrm{I}$ is white.

natalica has hindwings like those of cenea. The black pattern of the forewings is the same as that of hippocoonides but areas $\mathbf{I}$ and 3 are yellowish-buff to ochreous (8-19-9) like the hindwings and not white. Area 3 is often slightly reduced in size. salaami is like trophonius except that area $\mathrm{I}$ is orange (7-17-10) not white.

pale-poultoni is like salaami except that all the pale areas are a very pale orange (7-1 7-9).

bright-poultoni is like salaami except that all the pale areas are a bright reddishbrown (6-15-12) being of a deeper hue than area $\mathrm{I}$ in salaami or leighi.

niobe has the same general pattern as trophonius except that area $\mathbf{I}$ is the same reddish-brown colour $(6-15-12)$ as the rest of the pale areas. The body also has a decidedly reddish tint.

planemoides has hindwings like those of the local hippocoonides, the black in area 5 extending nearly to the cell. The black area 2 of the forewing is replaced by light orange-brown found also in $\mathrm{I}$ and $3(7-\mathrm{I} 5-\mathrm{II})$. Area 3 is reduced in size by the extension of the black pigment from the base of the wing. This black covers a triangular area extending from the base of the wing to about two-thirds of the way along the cell and halfway along the inner margin. Consequently though much of the wing is black there is a light orange-brown bar extending through areas I, 2 and the distal end of 3 .

leighi has a hindwing similar to that of cenea except that area 4 is often rather paler but never quite white. Area $I$ is orange $(7-17-10)$ and area 3 is black except for a large orange spot bordering area 2. A buff or white spot of the same size and shape and in the same position is found in cenea (plate 3, no. 6).

The male-like non-mimetic pattern of the female (plate I, no. I ; plate 2, no I) has the pale areas of the wings bright yellow (I I or I 2-1 9-9) and the insect has tails. A fuller description of the forms can be obtained from Ford (1936) and the standard works listed by him.

\section{RESULTS AND DISCUSSION}

\section{(i) Dominance between sympatric forms}

The genetic work (Clarke and Sheppard, I959a, I959b, and in preparation) has shown that the forms hippocoonides (including hippocoon and niavioides), natalica, cenea, trophonius, leighi, salaami, pale-poultoni, and the male-like forms, henceforth called yellow, are all determined by an autosomal sex-controlled multiple allelomorphic series (or very closely linked genes) and it is also very probable, although not yet formally proved, that planemoides, niobe and bright-poultoni are governed 
by allelomorphs at the same locus. Table 2 gives the female forms together with the allelomorphs and the genotypes that are known to give rise to them within their own race. It has been assumed for the purposes of this discussion that our interpretation of the genetic control of niobe, planemoides and bright-poultoni is correct. If this should prove not to be the case then the dominance relationships indicated by the tables should be reinterpreted as epistatic effects wherever these three forms are concerned. Reference to tables I and 2 will show that there are a number of allelomorph combinations which exist within the races but which we have not yet synthesised. The tables also show that a number of combinations will not occur in nature since the allelomorphs concerned are not found in the same race.

TABLE 2

\begin{tabular}{|c|c|c|}
\hline Phenotypes & Allelomorph & Genotypes \\
\hline $\begin{array}{l}\text { hippocoonides } \\
\text { cenea } \\
\text { natalica } \cdot \\
\text { trophonius } \\
\text { leighi } \cdot \\
\text { salaami } \cdot \\
\text { imperfect trophonius } \\
\text { yellow } \\
\text { bright-poultoni } \\
\text { pale-poultoni } \\
\text { orange-cenea } \\
\text { buff-cenea } \\
\text { niobe } \\
\text { red-brown cenea } \\
\text { planemoides }\end{array}$ & $\begin{array}{l}h \\
H^{c} \\
H^{n a l} \\
H^{T} \\
H^{L} \\
\ldots \\
\ldots \\
H^{i \prime} \\
H^{b p} \\
H^{p p} \\
\ldots \\
\dddot{H^{N i}}\end{array}$ & $\begin{array}{l}h h \\
H^{c} H^{c} H^{c} h H^{c} H^{n a} \\
H^{n a} H^{n a} H^{n a} h \\
H^{T} H^{T} H^{T} h H^{T} H^{c} \\
H^{L} H^{L} H^{L} H^{n a} H^{L} H^{c} H^{L} h \\
H^{L} H^{T} \\
H^{T} \mathcal{N}^{n a} \\
H^{y} H^{y} H^{y} h H^{y} H^{c} \\
H^{b p} H^{b p} H^{b p} h H^{p p} H^{T} \\
H^{p p} H^{p p} H^{p p h} \\
H^{b p} H^{c} \\
H^{p p} H^{c} \\
H^{N^{i}} H^{N i} H^{N i} h H^{T^{\prime}} H^{p^{\prime} l} H^{N i} H^{c} \\
\quad(\text { some insects only) } \\
H^{N^{i}} H^{c} \text { (some insects only) } \\
H^{P^{l} l} H^{P^{l}} H^{P l} h\end{array}$ \\
\hline
\end{tabular}

It will be seen from table 2 that of the seven heterozygotes between allelomorphs both of which when homozygous control mimetic patterns only two give an intermediate heterozygote. These two exceptions are of interest in themselves. One, that between planemoides and trophonius, which will not be particularly rare (about 0.6 per cent. of the population near Entebbe), gives on most occasions an insect indistinguishable from niobe and therefore a mimic of Bematistes poggei and not at a disadvantage phenotypically. However, the heterozygote is rather more variable both in the exact colour of the redbrown areas and in the degree of development of the black bar (area 2) than in niobe itself suggesting that, at the lower frequency of the heterozygote, selection has not stabilised the pattern as it has in the much commoner niobe proper. The second exception is the heterozygote between niobe and cenea in which the insect sometimes resembles niobe and sometimes is distinguishable from it. In this instance there is no appropriate model and the heterozygote itself, when detectable, resembles a cenea with the pale areas red-brown instead of the normal 
white and yellowish-buff. It will be moderately rare (about 0.4 per cent. or less) since neither of the allelomorphs in this heterozygote are common in races where both occur. Thus with the mimetic allelomorphs we find only one partial exception to the conclusion that disruptive selection will lead to the elimination of intermediates between optimum patterns.

When we examine the heterozygotes between allelomorphs, one of which controls a mimetic form and the other a non-mimetic one, we find there are thirteen in table 2 of which five are intermediate. These combinations in which dominance is absent are as instructive as the examples where both allelomorphs control mimetic patterns. Two of the five are not uncommon, one being the heterozygote between cenea and pale-poultoni and the other between cenea and bright-poultoni both of which resemble rather closely the cenea/niobe heterozygote. Now, except as great rarities, the allelomorphs $H^{b p}$ and $H^{p p}$ are only found in race polytrophus from Kenya, where the models for $P$. dardanus are uncommon and where consequently, the disruptive selection is much relaxed and many imperfect mimetic forms are found (Ford, I936). The third is that between trophonius and pale-poultoni and gives a form which is almost identical to bright-poultoni and would therefore not be expected to be disadvantageous from the point of view of its appearance. The fourth example of an intermediate heterozygote is found in South Africa and is between trophonius and natalica. This heterozygote, although not particularly uncommon, comprising up to perhaps I per cent. of the female population in some areas, is also not a bad mimic of Danaus chrysippus. In fact it only differs from trophonius in having a pale buff instead of a white area near the apex of the forewing (fig. 2, area I). In old specimens it is indistinguishable from trophonius and even in fresh specimens it is quite easy to score the insect as trophonius. In fact we have done this on one occasion and only discovered our mistake from the offspring of the mating. The last intermediate, salaami, also comes mainly from South Africa. Unlike the other forms it is very uncommon and cannot constitute more than 0.2 per cent. of the female population and may only account for 0.04 per cent. or less of the females in most populations. The form is very like bright-poultoni in appearance and quite unlike either homozygote (in addition to these five exceptions on rare occasions we have detected a modifier which makes leighi incompletely dominant to cenea). The breeding results, therefore, are consistent with the hypothesis that in mimicry, disruptive selection eliminates or materially reduces intermediate phenotypes except in the case of extremely rare heterozygotes or where the selection is weak or non-existent as in the polytrophus race.

There are two main hypotheses which could account for the absence of intermediate heterozygotes; (i) it could be argued that there was complete dominance from the first appearance of the mutant and that all disruptive selection can do is to stop allelomorphs with 
intermediate phenotypes in the heterozygote from spreading; or (ii) that the dominance was not present initially but that it evolved as the result of selection for a modifier or modifiers. In most material it is impossible to gather data which will distinguish between these two alternatives but in $P$. dardanus it is possible to obtain information on the matter by making suitable race crosses. If the first hypothesis is correct, one would expect complete dominance in most instances when one introduced an allelomorph from one race into the gene-complex of another which does not and has not possessed it. On the second hypothesis one would expect a breakdown in dominance if this procedure were carried out.

\section{(ii) Absence of dominance between allopatric forms}

Now in the Madagascan race of $P$. dardanus all the females are male-like, having the presumed primitive pattern of the species. The $F_{1}$ hybrids between this race and the main African stock females (in this case race cenea) of the forms hippocoonides, natalica and cenea are intermediate in appearance having the pale areas on the wings yellow and a black pattern rather similar to that of hippocoonides (plate I). Although the three genotypes give phenotypes which are very alike they are distinguishable from one another, each showing the effects of the particular allelomorph concerned. Thus the yellow areas in the hippocoonides heterozygote are a paler yellow (12-19-6) than either the Madagascan yellow (I I or I2-I9-9) or that of the other two heterozygotes and in the first backcross to the main African stock they are even a little paler still (12-19-5 or 6). The cenea heterozygote, although it has much the same black pattern as in the hippocoonides hybrid, is recognisably different since the pale areas near the apex (area I) and near the inner margin (area 3) of the forewing are smaller and the yellow is of a deeper hue (10-19-9). The natalica hybrid is also distinct, for although it has the same black pattern as the hippocoonides $F_{1}$ the yellow areas are of a deeper orange-yellow (8-18-8).

The only other heterozygote which we have produced, using the Madagascan race, concerns trophonius. The resulting phenotype is exceptionally variable. One of the extreme forms has the black pattern of hippocoonides but all pale areas orange-brown (areas 3 and 4 , 7-I6-II, area I, 7-I7-9), producing an insect very like salaami. The other is an almost exact replica of proto-trophonius from Kenya, having a tendency for the black bar (area 2) between the two pale areas ( 1 and 3) on the forewing to be reduced, the apical pale area pale yellow (1 2-19-3) not white, and a reduction of the area of red-brown in the forewing so that there is also an area of pale yellow near the reduced black bar (plate 2).

Since all four hybrid heterozygotes are dissimilar, and do not resemble the African homozygotes, or the Madagascan one, we can conclude with confidence that in the unadjusted gene-complex of the 
hybrid dominance is absent. It is therefore very probable though not yet formally proved, that there is no dominance with respect to the four African allelomorphs and yellow in the pure Madagascan genecomplex. The only other possibility is that the Madagascan race possesses modifiers which confer dominance and that its absence in the $\mathrm{F}_{1}$ hybrid is due to the recessiveness of some of these. The trophonius heterozygote is extremely variable. Since it is not variable in South African material the modifiers controlling the distribution of red pigment are likely to have come from the Madagascan race (see also the antinorii hybrids described below). This suggests that it is not well adjusted to this allelomorph. The trophonius homozygote in a Madagascan gene-complex can possess no yellow, since the allelomorph controlling this pigment will be absent, whereas the yellow homozygote can have no red. If the distribution of red is variable in the heterozygote, due to variations in the gene-complex, at least a proportion of the heterozygotes will be distinct from both homozygotes. Thus complete dominance will be absent.

It is also more than likely that the yellow pattern is not dominant in the main African stock since in the first backcross the hippocoonides yellow heterozygote is still much like the $\mathrm{F}_{1}$ even though the hippocoonides characters are slightly enhanced.

Besides being the only one in Madagascar, the yellow pattern is also the commonest in Abyssinia. However, in Abyssinia, forms resembling hippocoonides, trophonius and cenea are also found (table I). There is no report in the literature of cenea occurring in this area, but Mr Carcasson of the Coryndon Museum tells us that he saw a tailed form of cenea flying in Southern Abyssinia and Mr P. R. A. Mansfield of the British Embassy at Addis Ababa has sent us a photograph of a cenea with short tails which was caught near Filfil in Eritrea.

Similar crosses to those with the Madagascan race have been made using Abyssinian material but the results are quite different, as might be anticipated on our hypothesis, since some of the allelomorphs are common to both the Abyssinian and main African races. The only two Abyssinian phenotypes we have so far used are the yellow and hippocoonides forms. We found that the natalica/hippocoonides, cenea/hippocoonides and trophonius/hippocoonides heterozygotes produced normal natalica, cenea and trophonius respectively. However, the interesting heterozygotes from the point of view of comparison with the Madagascan crosses are the ones with the yellow allelomorph. The hippocoonides/ yellow heterozygote is indistinguishable from the pure Abyssinian yellow form except that the black areas on the hindwing are joined up into a black border (area 5) as in hippocoonides. The cenea/yellow heterozygote is identical with the previous heterozygote except that the yellow is of a deeper hue (8-I 7-9) and a few black scales are sometimes found in area 2. The deeper yellow can also occur in some hippocoonides/yellow heterozygotes (plate 2). Thus, in the $F_{1}$ the dominance of the yellow pattern over hippocoonides and cenea is almost complete 
and, after one backcross to the Abyssinian race, dominance is complete in both forms since even the black pattern of the hindwing is identical with that of the Abyssinian yellow form and the deeper yellow shade is also absent (plate 3). On backcrossing the yellow hippocoonides heterozygote into a hippocoonides strain of the main African stock, the hippocoonides characters become more and more enhanced and in the second and third generations the yellow insects are almost identical with those of the Madagascan race hybrids of the first backcross (plate 2).

The natalica/yellow $\mathrm{F}_{1}$ heterozygote (8-I $\left.7-8\right)$ is almost identical with the cenea/yellow heterozygote except that there is a strong tendency for the black bar, area 2, near the apex of the forewing to appear (plate 2). Thus the dominance of the yellow form is less complete in this heterozygote.

The results so far are in accord with the hypothesis that disruptive selection has built up the dominance of yellow in the polymorphic Abyssinian race but not in the monomorphic Madagascan one. Even the less complete dominance of yellow over natalica is in accord with this view since natalica is not known in the Abyssinian race. The results with trophonius also help to confirm the hypothesis although at first sight they might be thought to contradict it. Despite the fact that a trophonius-like form is found in Abyssinia (table I) our trophoniusyellow heterozygote is intermediate between trophonius and yellow. The insects are variable but they have the hindwing pattern of trophonius. In the forewing the red-brown pigment is present in its normal position but it is also found to a variable degree in the normally white area near the apex of the wing (area I), the rest of this area being yellow. The normal black bar (area 2) between these two pale areas is absent and replaced by yellow (plate 2). Thus the heterozygote is similar to the same heterozygote in the Madagascan racecross, except for the absence of the black bar, and dominance is absent.

In all collections from Abyssinia no insect remotely resembling this form has ever been found despite the fact that several trophonius-like insects have been caught. Now the heterozygote will be much commoner than the rarer homozygote so that we must either conclude (i) that the trophonius form in Abyssinia is not controlled by the same gene as is the South and Central African form, in which case the intermediate heterozygote is just what would be expected on the hypothesis we are examining, or (ii) that on backcrossing into the Abyssinian gene-complex the form would either become completely dominant or completely recessive, which would also fit the hypothesis.

Three other allelomorphs, not known to occur in race antinorii and not included in the Madagascan race-crosses, have been used in making Abyssinian hybrids. The first $H^{L}$ produces an insect resembling leighi in the $H^{L} h \mathrm{~F}_{1}$ hybrid but in later generations (first backcross to main African stock and $F_{2}$ ) the heterozygotes were found to produce rather variable results, some insects being like planemoides and othe $\mathrm{rs}_{\mathrm{s}}$ 
like leighi, the rest having intermediate patterns. No. $\mathrm{F}_{1}$ hybrid heterozygote between leighi and cenea $\left(H^{L} H^{c}\right)$ has been made. However, this heterozygote has been produced in the first and second backcross to the main African stock and in both broods it is quite distinct from either leighi or cenea. It has the leighi colouring and pattern save that the pale area near the apex of the forewing (area I) is reduced in size and shows a tendency to be divided by black into several distinct spots. Thus on introducing part of the gene-complex of antinorii into the main African stock the complete dominance of leighi over cenea is removed. The leighi/yellow heterozygote is variable and intermediate in appearance between leighi and yellow. It resembles the hippocoonides/yellow $\mathrm{F}_{1}$ hybrid except that area $\mathrm{I}$ has a marked orange-red flush due to the presence of many orange scales, there is sometimes a reduced black bar in area 2 and there are some orange scales in area 3 bordering both area 2 and the cell.

The second allelomorph is $H^{b p}$ which controls the bright-poultoni pattern. The phenotype of the heterozygote with yellow, $H^{b p} H^{y}$ is also intermediate between the two homozygotes since the distribution of black pigment is the same as that in the other hybrids (area 2 being pale not black) but the yellow areas are replaced by red-brown (7-I5-12). This insect is an almost exact replica of the form dorippoides which is only found, as a rarity, in East Africa. The $H^{b p h}$ heterozygote also looks like dorippoides (though less extreme) so that we cannot say whether the dominance has broken down or not, only that in the heterozygote the normal bright-poultoni phenotype has been altered. In pale-poultoni we know that the heterozygote with yellow is intermediate in appearance. Thus all our results so far reported are consistent with the presence of dominance between forms which are sympatric, common and subject to strong disruptive selection and its absence between most allopatric forms.

\section{(iii) The genetics of the tailed condition}

There is one feature of the Madagascan, Grand Comoro and Abyssinian races, other than the presence of the male-like pattern of the females, not found in any other race, namely the presence of tails, all being monomorphic in this respect. Now the presence or absence of tails is controlled by a pair of allelomorphs $t$ and $T$ whose locus is sex-controlled, autosomal and not linked to that controlling colour pattern. The allopatric tailed form of the Madagascan race produces short tails of variable length in the heterozygote with the main African stock (tables 3 and 4 ). The tails are further reduced in the first backcross to the African stock since in all the tailed individuals the tails never exceeded the length of the shortest ones in the $F_{1}$ hybrid ( $2 \mathrm{~mm}$.).

In the similar hybrid using the Abyssinian race the heterozygotes are tailless in almost half of the individuals and the rest have short tails similar to the less extreme of the Madagascan hybrids, this difference between the two race-crosses being significant $(\mathrm{P}<\mathrm{O} .0 \mathrm{I})$. Thus 
the dominance of taillessness is complete in many individuals of the $F_{1}$ and in fact also in the first backcross into the Abyssinian race

TABLE 3

Types of tails and genotype

\begin{tabular}{|c|c|c|c|c|}
\hline \multicolumn{2}{|c|}{ Hybrid } & None $(T t)$ & Short $(T t)$ & Long $(t t)$ \\
\hline mer. $\times a f r$ & $\mathrm{~F}_{1}$ & 0 & 8 & 0 \\
\hline $\begin{array}{l}\text { ant. } \times \text { afr } . \times a f r .) \\
F_{1} \times a n t .\end{array}$. & $\begin{array}{l}F_{1} \\
B_{1}\end{array}$ & $\begin{array}{r}29 \\
9\end{array}$ & $\begin{array}{l}3 \mathrm{I} \\
\mathrm{IO}\end{array}$ & $\begin{array}{r}0 \\
22\end{array}$ \\
\hline
\end{tabular}

$T$ is the allelomorph controlling the tailless condition. mer., ant. and afr., stand for the races meriones from Madagascar, antinorii from Abyssinia and the main African stock respectively. The distinction between short and no tails is a somewhat arbitrary one based on the appearance of the wing. Besides the 8 meriones $\mathrm{F}_{1}$ hybrids there were I I others all of which had short tails but these have not been measured since they were damaged while being used for breeding.

(table 3). The reason for the greater degree of dominance in the Abyssinian cross becomes clear when we compare the pure Madagascan

TABLE 4

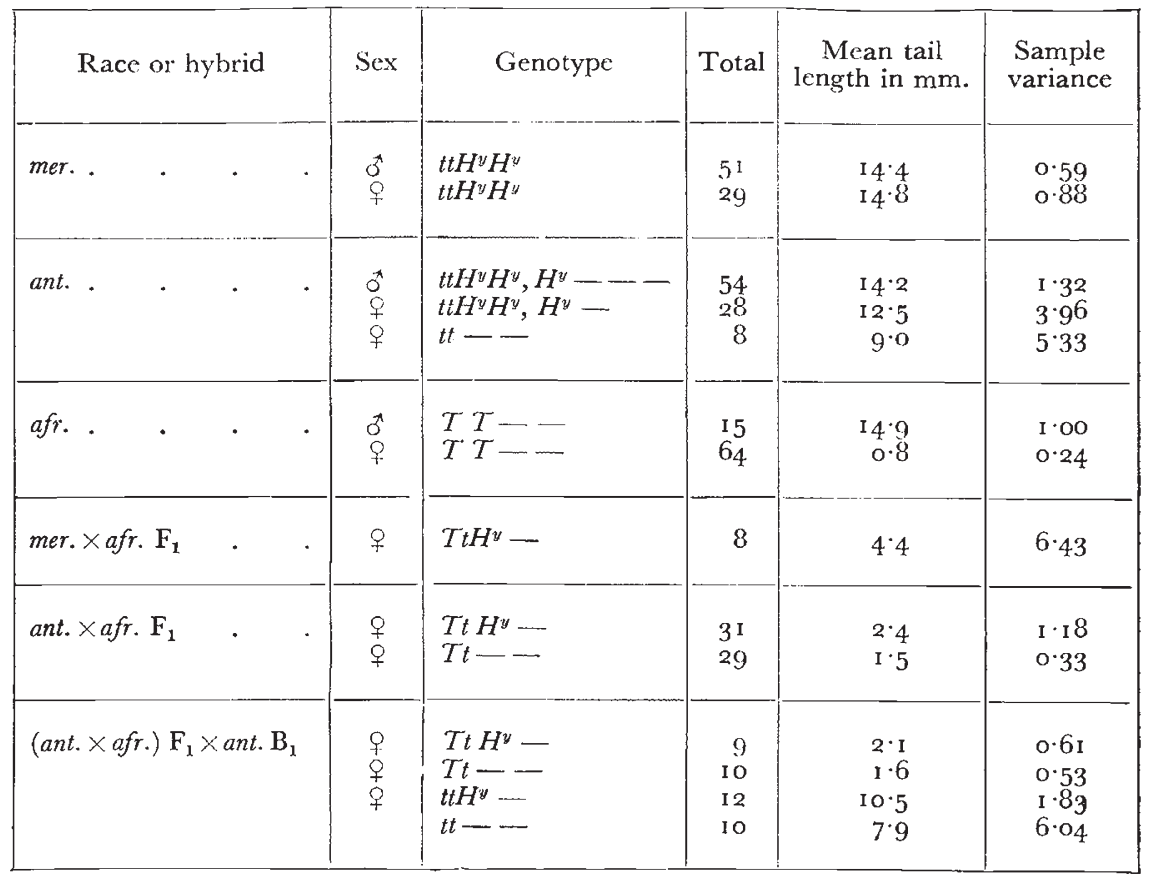

The abbreviations and genetic symbols are the same as in table 3 with the addition of $H^{v}$, which denotes the presence of the gene controlling the non-mimetic yellow pattern, and - which signifies the presence of one of the other allelomorphs of this series.

and Abyssinian races. On measuring the length of the tails of the Madagascan and Abyssinian females we find that the mean length of 
those from Abyssinia is less than those from Madagascar, particularly the mimetic females (table 4). This would be expected since in the absence of the gene $T$ for the tailless condition there will be selection for modifiers reducing the length of the tails in the mimetic females so that they conform more closely to the tailless models. These modifiers would presumably also act in the heterozygotes thus accounting for the complete dominance in some $F_{1}$ hybrids. Thoday (r959) has found that disruptive selection increases the variance of a population. It is therefore of some interest that the variance of tail length is greater in the Abyssinian females (particularly the mimics) than in the Madagascan and main African stock males as well as the Madagascan females (table 4). Now there would be no selection for the absence of tails before mimicry was evolved. But in the main African stock there must have been a considerable period of selection between the evolution of mimicry and the elimination of the tailed forms by the spread of the allelomorph for the tailless condition. During this period there would be selection for modifiers reducing tail length, as in Abyssinia today, and the continued presence of some of these in the main African stock would help to increase the dominance in the Abyssinian cross and also account for the reduced tail length in the Madagascan first backcross to the main African stock.

\section{CONCLUSION}

Although it is impossible to prove that dominance was absent when the allelomorphs controlling the mimicry of $P$. dardanus first arose, since these events are long past, the evidence from the race-crosses strongly supports such an hypothesis and further suggests that dominance has been evolved owing to the action of disruptive selection as suggested by Sheppard (1958). Furthermore there are also data which suggest that modifiers for the reduction of a character (tail length) can also lead to the evolution of dominance even in the absence of the character (taillessness) whose dominance is being affected. Our results are therefore in accord with the hypothesis put forward by Fisher (1928) that dominance is not a fixed attribute of a particular allelomorph but is modified by natural selection during the course of evolution.

\section{SUMMARY}

r. The various mimetic and non-mimetic female forms of the butterfly Papilio dardanus appear to be controlled by a multiple allelomorphic series or by closely linked genes whose effect is sex-controlled.

2. There is complete dominance between the sympatric forms except for a minority, 7 heterozygotes out of $2 \mathrm{I}$ tested, and here the forms concerned are either very rare or the heterozygotes resemble some other polymorphic form or selection for a close resemblance between model and mimic is relaxed on account of the rareness of the models. 
3. Hybrids have been made between the main African races and those found in Abyssinia and Madagascar. The results suggest that hybrids between allopatric forms, in contrast to sympatric ones, much more rarely show complete dominance; there being 12 intermediate heterozygotes in 14 tested.

4. The results are in agreement with the view that, where there are two optimum phenotypes controlled in part by a pair of allelomorphs, disruptive selection will result in the heterozygote and one homozygote coming to resemble one optimum phenotype and the second homozygote coming to resemble the other.

5. In the main African races the females, unlike the monomorphic males, are tailless whereas the Madagascan and Abyssinian ones invariably have tails. Their absence is controlled by a single locus independent of that controlling colour-pattern.

6. Like the colour patterns, the absence of tails is incompletely dominant to the allopatric tailed condition. Dominance is more complete in the Abyssinian race-crosses than in those using the Madagascan form. In contrast to the monomorphic non-mimetic Madagascan females the Abyssinian females, particularly the mimetic ones, have shorter tails than the males. It is suggested that this results from the accumulation of modifiers, as the result of disruptive selection, for the reduction of tail length in the mimics and that these modifiers acting in the heterozygote increase the dominance of the tailless condition.

7. Our results strongly indicate that dominance between two unifactorially controlled characters is often absent initially but can evolve as the result of disruptive selection even in the absence of one of the two characters. The selection, however, is likely to be effective more rapidly if the populations are polymorphic for the two.

Acknoweledgments.-We are greatly indebted to Dr E. B. Ford, F.R.s., for his encouragement and for his detailed criticism of the manuscript. We should also like to thank Dr G. A. Harrison, Professor K. Mather, F.R.s., Professor R. J. Pumphrey, F.R.s., and Dr S. Walker for their helpful comments. The genetic analysis of the Kenyan, Abyssinian and Madagascan races would not have been possible without the information and material so kindly sent by Dr V. G. L. van Someren, Mr R. W. Carcasson, Mr P. R. A. Mansfield and Mr Michael Wells. Without the generous aid of the Nuffield Foundation this work could not have been carried out.

\section{REFERENCES}

CLARKE, C. A., AND SHePPARD, P. M. 1959a. The genetics of some mimetic forms of Papilio dardanus, Brown, and Papilio glaucus Linn. 7. Genet., 56, 236-26o.

CLARKe, C. A., AND Sheppard, P. M. I959b. The genetics of Papilio dardanus Brown. 7. Genet. (in press).

FISHER, R. A. 1928. The possible modification of the response of the wild type to recurrent mutations. Amer. Nat., 62, I I 5-I 26.

FORD, E. B. 1936. The genetics of Papilio dardanus Brown (Lep.). Trans. Roy. Ent. Soc. Lond., $85,435-466$. 


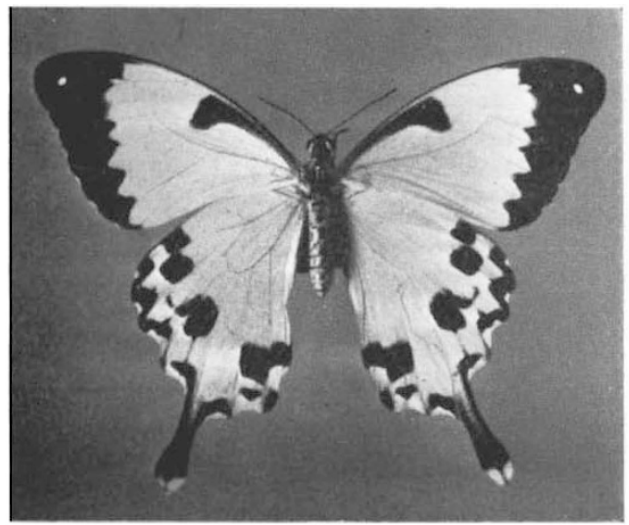

( 1$)$

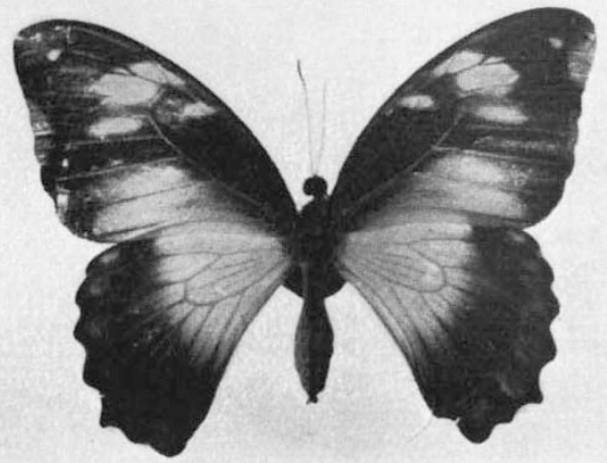

(3)

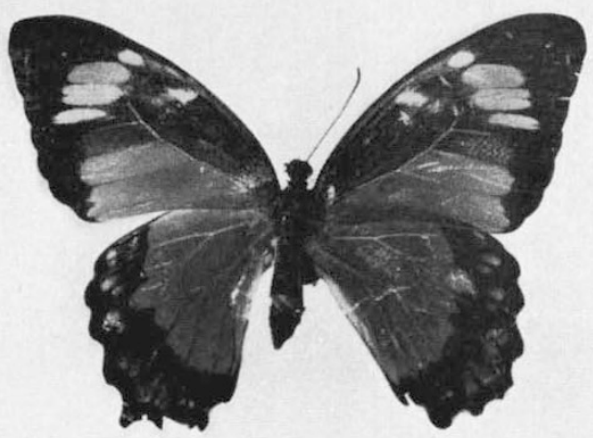

(5)

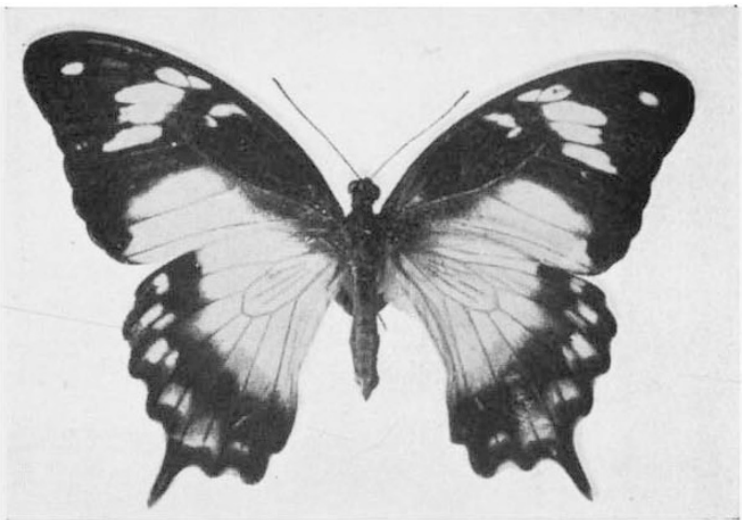

(2)

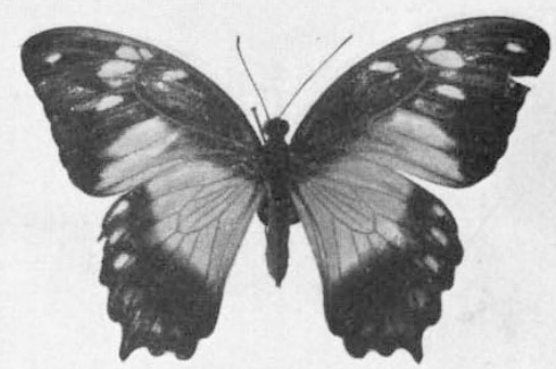

(4)

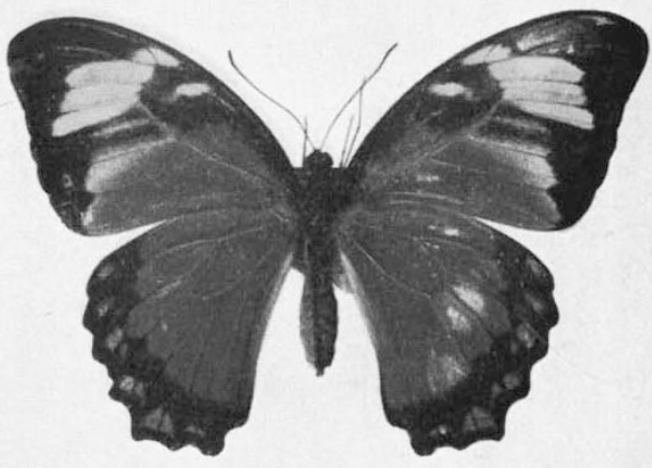

(6)

Plate I

meriones and $\mathrm{F}_{1}$ hybrids ( 1 ) meriones male-like female, (2) hippocoonides/yellow heterozygote,

(3) natalica/yellow heterozygote, (4) cenea/yellow heterozygote. (5 and 6) extreme forms of trophonius/yellow heterozygote. 


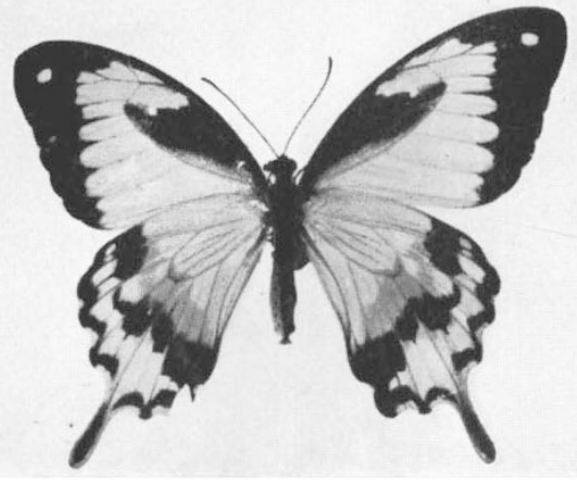

(1)

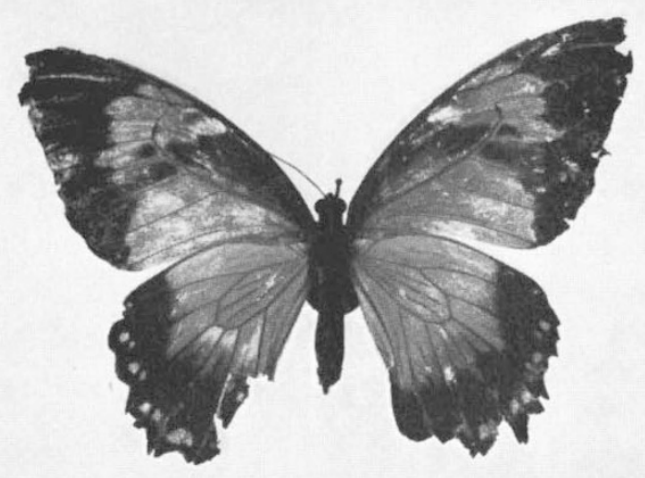

(3)

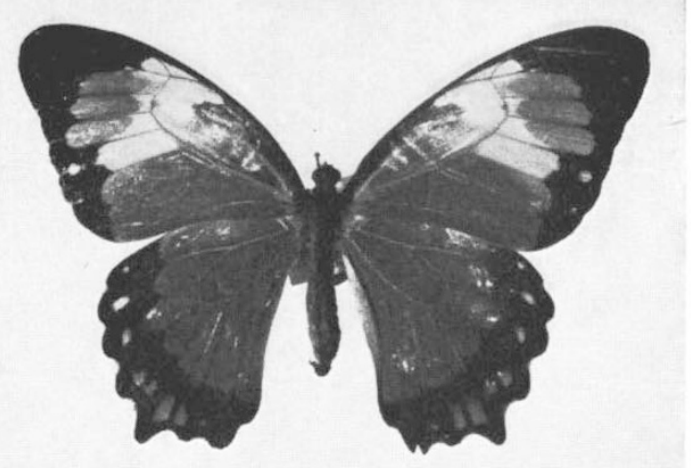

(5)

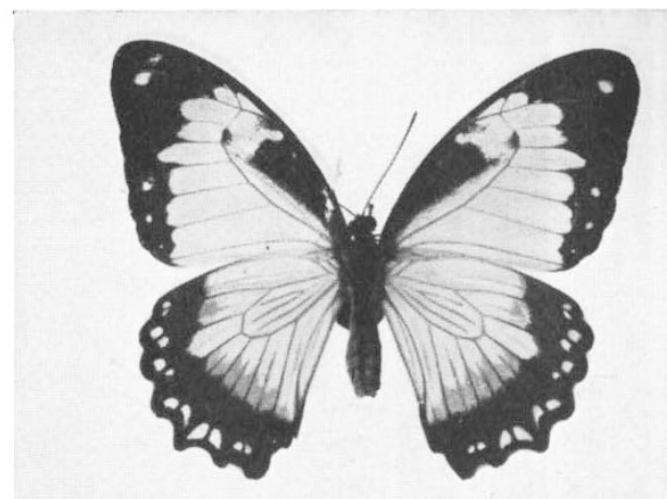

$(2)$

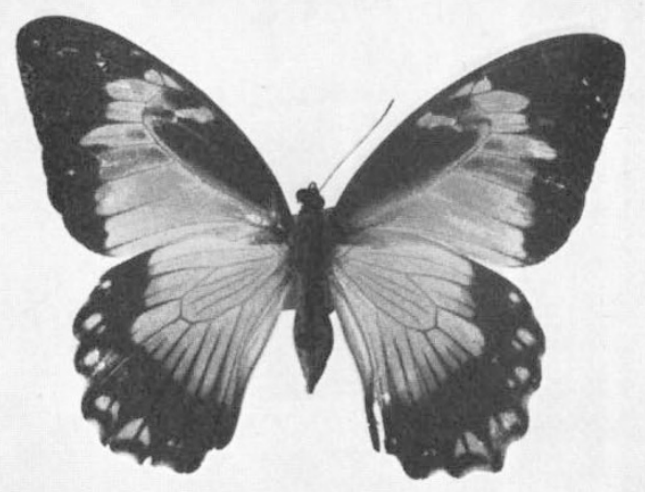

(4)

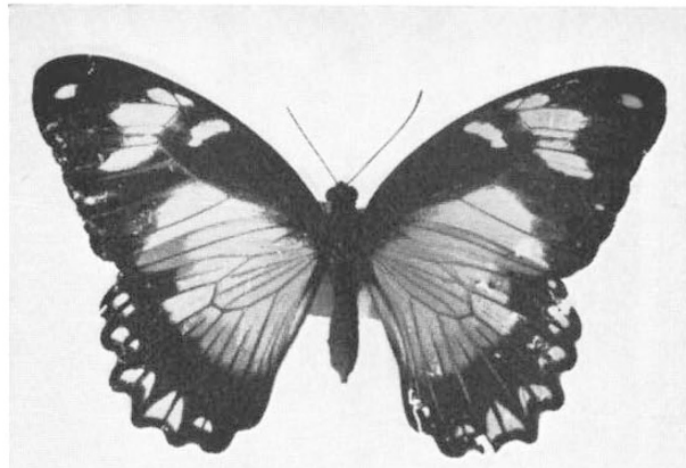

(6)

Plate II

antinorii and $\mathrm{F}_{1}$ hybrids. (1) antinorii male-like female, (2) hippocoonides/ycllow heterozygote, (3) natalica/yellow heterozygote, (4) cenea/yellow heterozygote, (5) trophonius/ yellow heterozygote, compare with plate I, 5 and $6,(6)$ 2nd backcross to main African stock hippocoonides/yellow heterozygote. Note difference from 2. 


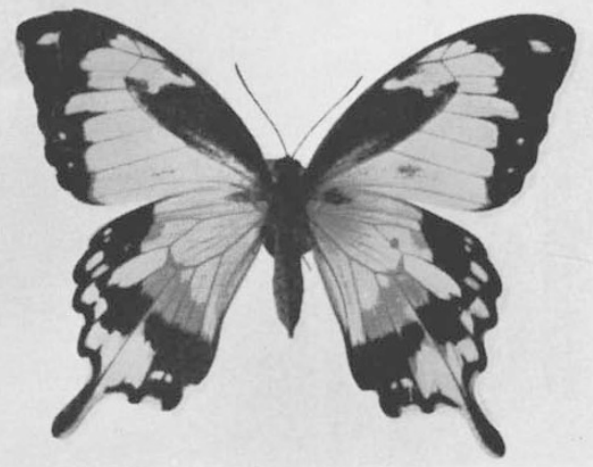

(I)

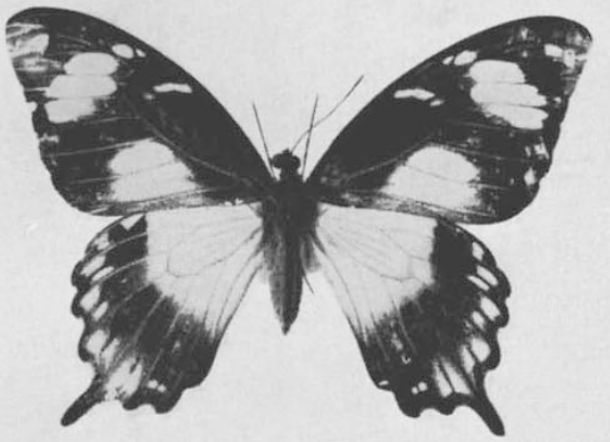

(3)

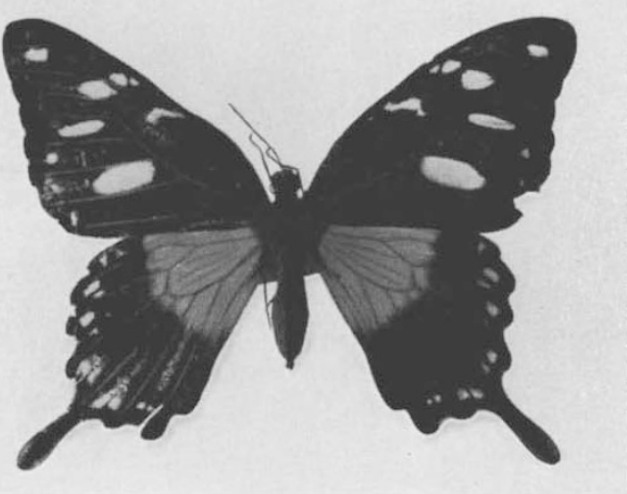

(5)

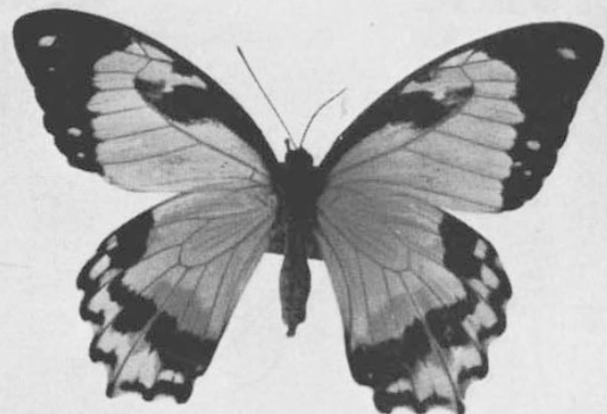

(2)

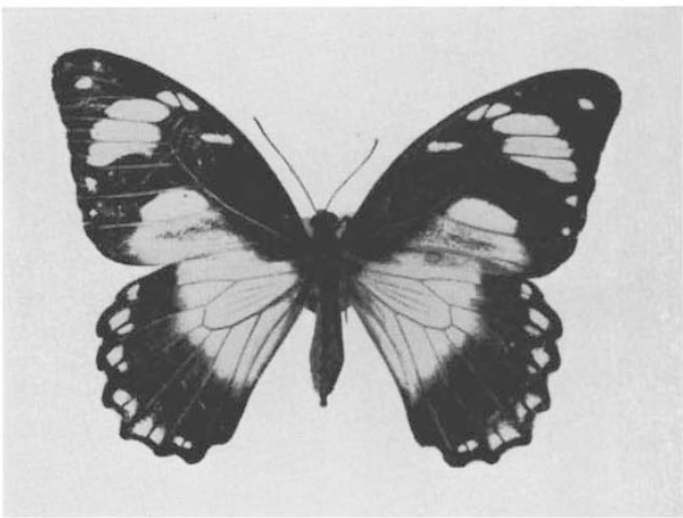

(4)

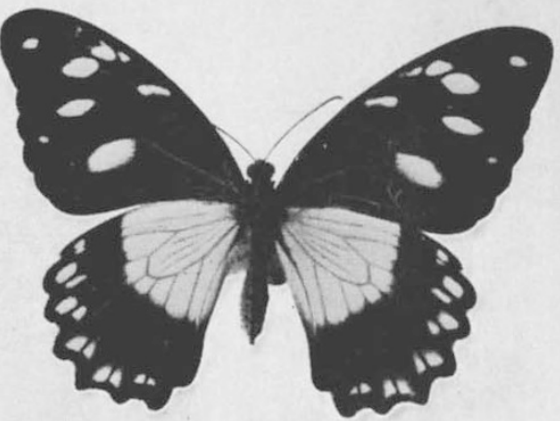

(6)

Plate III

First backcross to antinorii. ( 1 and 2) The insects are either hippoconides/yellow or cenea/ yellow heterozygotes, ( 3 and 4 ) hippocoonides homozygotes ( 5 and 6 ) cenea/hippocoonides heterozygotes. Note $(a)$ independent assortment of pattern and tailless condition, (b) the yellow antinorii like hindwing of 1 and 2 as compared with plate II, nos. 2 and 4 , (c) the completc dominance of yellow over cenea. Compare plate II, no. 4 and plate I, no. 4 . 
FORD, E. B. I953. The genetics of polymorphism in the Lepidoptera. Advanc. Genet., 5, 43-87.

FORD, E. B. 1955. Polymorphism and taxonomy. Heredity, 9, 255-264.

MATHER, K. 1955. Polymorphism as an outcome of disruptive selection. Evolution, 9, 52-61.

Sheppard, P. M. 1958. Natural Selection and Heredity. Hutchinson, London.

THODAy, J. M. 1959. Effects of disruptive selection. Proc. 15th Int. Cong. Zool., 1 27-1 30.

villalobos, C., ANd villalobos, J. 1947. Colour Atlas. Buenos Aires, El Ateneo. 